\title{
RESEARCH OF COGNITIVE EXCHANGE SPECIFICS IN TEACHERS ACADEMIC TRAINING
}

Dr. Gergana Dyankova, Faculty of Pedagogy, South-West University “Neofit Rilski”, Blagoevgrad, Bulgaria

E-mail: diankova_g@swu.bg

A R T I C L E I N F O
Original Research
Received: August, 24.2018.
Revised: October, 20.2018.
Accepted: November, 10.2018.
doi:10.5937/ijcrsee1803001D
UDK
159.953.5.072-057.874(497.2)

Keywords:

higher pedagogical education, learning environment, cognitive exchange, proactivity.

\begin{abstract}
A B S T R A C T
The paper discusses the transformation of the educational environment issues of university pedagogical subjects. The ideas of constructivism and connectivity, of moral philosophy and social psychology, are fundamental. By defining the content parameters of the educational environment in their dichotomous condition: reproducibility - proactivity; customization - dialogue; individualization - differentiation, this research highlights the specific characteristics of the learning process, which determine the qualitative cognitive exchange in the academic training of pedagogical subjects. A compound research is conducted of the learning by registering the self-assessment and the parallel-reflecting assessment of the students in the pedagogical specialties. The analysis of the results emphasizes the urgent need to change the traditionally established patterns in the organization of the teaching process in the higher pedagogical education, the application of student-oriented practices to stimulate self-organization in learning, the development of proactive technology incorporating the characteristics of formal and nonformal education in a networked and technological environment.
\end{abstract}

(C) 2018 IJCRSEE. All rights reserved.

\section{INTRODUCTION}

In recent years, the topic of modernizing higher education undoubtedly attracts attention, as it unifies the interests of society in general and rationally becomes a socially significant issue. Efforts to resolve it are addressed both at the regulatory level and through the search, research, and implementation of innovative educational approaches and strategies.

The higher education institution in Bulgaria (Article 6 of the Higher Education Act) is a legal entity with the following activities: training of specialists able to develop and apply scientific knowledge in different fields of human activity; increasing the qualification of specialists; development of science, culture, and innovation.

As such definition, the activity subject

Corresponding Author

Dr. Gergana Dyankova, Faculty of Pedagogy, South-

West University "Neofit Rilski", Blagoevgrad,

Bulgaria, E-mail: diankova_g@swu.bg

\section{(c) (†) $\odot$}

This work is licensed under a Creative Commons Attribution - NonCommercial - NoDerivs 4.0. The article is published with Open Access at www.ijcrsee.com of the higher education institution is also corresponding with the increasingly necessary lifelong learning approach, popular as "learning from the cradle to the grave".

It is unsatisfactory that in parallel with well-defined educational services/activities of the higher education institution, in recent years, unsatisfactory results have been registered in all educational levels. This is a disturbing symptom of the education system as it questions the "conditions in which learners acquire knowledge and skills" (Mavrodieva, 2009). It suggests an analysis of the ratio between the objectives set, the inputs, the actions taken, the results achieved and the impacts achieved.

A significant reason of working towards improving the quality of higher education training is also the report of the European Commission "Monitoring Education and Training 2017 - Bulgaria", which insists on "further improving both the applicability of higher education to the labor market thus and its quality".

The cited recommendation focuses on objectively clarifying the reasons for a significant disparity between the development of innovative education policies, adequate to the 
needs of the globalizing world, and the willingness (degree of competence) of university lecturers to implement them.

This contradiction is particularly acute about the issues of the educational environment transformation in university pedagogical subjects - as an environment that is at the output of the educational system and is committed to the production of competent specialists - future teachers. The methods used in their training "do not yet sufficiently contribute to provoking independency, expressed in selforganization, self-realization, self-evaluation" (Vardareva, Pashova, 2012).

The term "educational environment" (Yasvin, 2001), represents "the system of influences and conditions for forming the personality by a given model, as well as the possibilities for its development, contained in the social and spatial subject environment".

Placing the "learning environment" at the center of the forming work in the higher pedagogical education requires a well-founded system of criteria and indicators to record/ assess its educational potential. This focuses on the study of the specific formative interactions that structure the cognitive exchange in the learning process and influence the group dynamics in the educational environment.

It is precisely this finding that justifies the research and practical-applied value of scientific research, the aim of which is to study the specifics of cognitive exchange in academic teacher training.

The following analysis identifies resources for enhancing the quality of cognitive exchange in the learning process by including internships of university lecturers as well as using external invasive technologies stimulating proactive thinking and behavior.

Fundamental determinants for the realization of qualitative cognitive exchange in the learning process are its characteristics in terms of reproducibility - proactivity, personalization - dialogue, individualization - differentiation. It is in their manifestation that the competences of the teacher are reflected:

- to regard the form of pedagogical communication;

- to refine the choice of educational technology; factor;

- to consider the role of the personal

- to update the pedagogical reflection in view of the current role-playing scenario.

The presented study is the result of an approbation of research activities conducted in 2018 at South-west University "Neofit Rils- ki” - Blagoevgrad, Bulgaria.

\section{MATERIALS AND METHODS}

Vital to this study are the ideas of constructivism and connectivity, as well as current developments in the field of moral philosophy and social psychology.

According to constructivist theory, man is constructed in the social environment. The psychological basis of constructivism brings forward a special relationship to the human physical and social reality and emphasizes the activity of man. By combining multiple philosophical and scientific views of an interdisciplinary nature, constructivism clarifies the peculiarities of man's actions as a self-organizing system. The point of reference for the acquisition of knowledge is the social interactions between the subjects in the learning process. Thus, the static approach to learning and training, which is also embedded in the ideas of connectivity, is actually overcome.

According to Connectivism theory (Siemens, 2005), in the information age, the learning process is characterized by:

1) Sociality of learning - knowledge is a dialogue between the teacher and other members of society, and the dialogue is secured with resources, dynamic and interrelated;

2) Collaborative understanding and creation of meaning and knowledge - Many and rapidly developing educational communities that foster a strong learning development from one another are being built;

3) Diversity - the structured and planned curriculum is defined as inappropriate, outdated and "outmoded";

4) The fundamental importance of relationships - the effect of networking has been proven;

5) Learning is not linear (cause-consequence), but circular (systematic) acquisition of knowledge - the basis of the learning process is self-organization.

On a personal level self-organization is defined as a process of constructing knowledge within the institutional and network environments "until they become internal goals and efficient motivators for action and personal thought" (Milenkova, Peicheva, Marinov, 2018).

These statements support the thesis that in the present time "agents of subjective activity are the practical skills of orientation and actions in an environment saturated with in- 
formation media, thus the realization of this unconditional necessity implies a specific outline of the paradigm for changing the educational process in the Bulgarian educational system" (Dermendzhieva, 2006).

Nevertheless, current research in the field of education clarifies that:

- Knowledge is rather abundant and is incomprehensible - how to choose the best;

- Knowledge is not "inside" the institution but in human and computer networks;

- Learning is a process running in an unclear surrounding environment by changing elements that are not entirely subject to human control;

- Learning is increasingly being implemented on a variety of paths - through practical social communities, personalized networks, and ongoing tasks (Ivanov, 2011).

Capitalizing knowledge in today's education system is an investment in human resources. These ideas are multifaceted with Kurt Lewin - about the active and passiveadaptive tendencies in behavior motivation (Lewin, 1980), with Viktor Frankl - about the proactiveness of searching for significance (Frankl, 2000), with Stephen Covey - realizing self-values (Covey, 2010).

These social and psychological concepts fill with content the logic and acceleration of cognitive exchange in a proactive educational environment. Moreover, it reflects the procedural essence of the development of a qualitative educational process in which cognitive exchange achieves personally significant effects on the basis of complementing traditional know-how and know-what with know-where to find the necessary knowledge.

\section{RESEARCH PROGRAM}

For the purposes of this research, a program has been developed that covers the following stages:

- FIRST STAGE: Inquiring the theoretical basis on the essence and characteristics of innovative educational approaches: This stage involves systematic follow-up of literary sources and basic theoretical representations reflecting the multi-aspect of the ideas that are objectively related to the research problem.

- SECOND STAGE: Development of research tools of the specificity of cognitive exchange in academic teacher training: At this stage, the research methodology, which aims to typify the cognitive structure of the learning environment in higher pedagogical education, is investigated and justified. The focus of the study is the specificity of cognitive exchange in the learning process - with its generalization, dynamism and integral integrity. The understanding that the overall organization of the learning environment is based on the principles of the activity of the interacting subjects is confirmed.

This determines that the criteria introduced should have a higher degree of diagnostic capability to reflect the imminent trends, patterns, and peculiarities.

In this connection, the content of the educational environment is determined. They identify the components that are prioritized in the idea of the new educational paradigm for the subject-subjective interaction in the learning process. The same, for the purposes of the present study, are defined by their dichotomous conditionality:

- Reproducibility - proactiveness;

- Personalizing - dialogizing;

- Individualization - differentiation.

Their objective recognition is based on certain indicators through which their presence or absence is recorded in the learning environment (Table 1.). 
Table 1. Content of the educational environment and indicators, structuring the cognitive exchange

\begin{tabular}{|c|c|c|}
\hline № & $\begin{array}{l}\text { Comp } \\
\text { onents }\end{array}$ & Indicators structuring the cognitive exchange \\
\hline \multirow{8}{*}{1} & \multirow{8}{*}{ 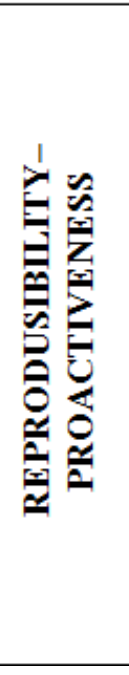 } & $\begin{array}{l}\text { Problem-based learning: learning in context, understanding ideas and concepts } \\
\text { through direct demonstration and research in a realistic context. }\end{array}$ \\
\hline & & $\begin{array}{l}\text { Distributed learning: discovering the links between the different subject areas and the } \\
\text { application of the material studied in different aspects of life. }\end{array}$ \\
\hline & & $\begin{array}{l}\text { Cooperative based learning: Reconstruction of Knowledge through Networking } \\
\text { learning. }\end{array}$ \\
\hline & & $\begin{array}{l}\text { Inquiry-based learning: continuous observation, asking questions, making } \\
\text { assumptions,| testing hypotheses, formulating concepts. }\end{array}$ \\
\hline & & $\begin{array}{l}\text { Game based learning: creating conditional situations with highly relevant context and } \\
\text { dialog activity. }\end{array}$ \\
\hline & & $\begin{array}{l}\text { Web-based learning: is a collection of all training activities that are used in the World } \\
\text { Wide Web (WWW) and is the main component of eLearning. }\end{array}$ \\
\hline & & $\begin{array}{l}\text { Incidental learning: performing tasks that unexpectedly deepen specific knowledge } \\
\text { and skills. }\end{array}$ \\
\hline & & Student teaching: the student is in the role of a lecturer in a regulated environment. \\
\hline \multirow{16}{*}{2} & \multirow{16}{*}{ 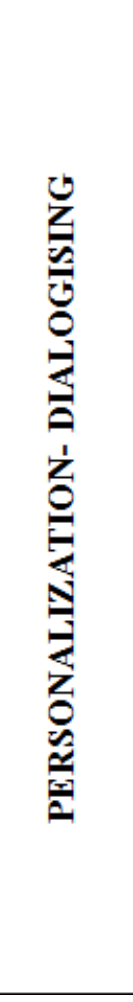 } & Techniques for creating a favorable atmosphere: organization of communication. \\
\hline & & Grouping and regrouping techniques. \\
\hline & & Face-to-face interaction techniques: group work, teamwork, working with a partner. \\
\hline & & Energizing techniques for activating cognitive exchange. \\
\hline & & $\begin{array}{l}\text { Techniques for generating ideas: brainstorming, associative cloud, mental maps, } \\
\text { visualizations. }\end{array}$ \\
\hline & & Feedback techniques. \\
\hline & & $\begin{array}{l}\text { Strategies for building a positive relationship: working in an information network, } \\
\text { expert problem solving, interpersonal experimentation. }\end{array}$ \\
\hline & & $\begin{array}{l}\text { Strategies for presenting personal creativity: the project method, the method of } \\
\text { concrete situations. }\end{array}$ \\
\hline & & Strategies for developing individual competence: modeling, design. \\
\hline & & $\begin{array}{l}\text { Strategies for constructing opinions and preferences: analysis, synthesis, selection of } \\
\text { information, synergy. }\end{array}$ \\
\hline & & Group Analysis Strategies: Sharing, Comparing, Debating. \\
\hline & & Strategies for Developing Critical Thinking and Defending Ideas. \\
\hline & & $\begin{array}{l}\text { Strategies for encouraging the student's initiative in constructing knowledge: } \\
\text { Demonstration, conducting the activity into an appropriate regulated environment. }\end{array}$ \\
\hline & & Individual differences and fluctuations in the learning process are considered \\
\hline & & $\begin{array}{l}\text { It is reported that the mental processes of learners are influenced by their social and } \\
\text { cultural identity. }\end{array}$ \\
\hline & & It is approached with understanding when giving feedback. \\
\hline \multirow{12}{*}{3} & \multirow{12}{*}{ 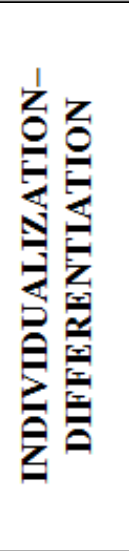 } & Practices with ongoing self-assessment and refiection are used. \\
\hline & & Research, experimentation, independent study is encouraged. \\
\hline & & Contractual learning - training in real organizations based on contracts is applied. \\
\hline & & Volunteering in educational institutions is encouraged. \\
\hline & & Internship is applied. \\
\hline & & The involvement of students in learning communities and groups is encouraged. \\
\hline & & Expert learning is applied. \\
\hline & & Learning through experience. \\
\hline & & Learning through activities. \\
\hline & & Differentiates tasks according to learning styles. \\
\hline & & Provides time for consultation in real and virtual environments. \\
\hline & & Promoting interpersonal communication in the learning process. \\
\hline
\end{tabular}


- THIRD STAGE: Researching the specificity of cognitive exchange in the educational process of the example of higher pedagogical education at South-West University "Blagoevgrad", Neofit Rilski. At this stage the actual research of teachers and students from the professional fields 1.2. "Pedagogy" and 1.3. "Pedagogy of Training on ..." was conducted.

The aim of the research is to typify the cognitive structure of the learning environment in the higher pedagogical education. The subject of the study is the content parameters of the educational environment in the academic education of teachers in terms of: reproducibility-proactiveness; personalizing - dialogizing; individualization-differentiation.

The subject of the study is the specific formative interactions that structure the cognitive exchange in the learning process and influence the group dynamics in the educational environment. On the basis of the formulated content parameters of the educational environment, identical matrixes were developed as follows:

- "Matrix for Teachers' Self-Assessment of the Learning Environment" - records the main aspects of teaching practices as indicators of the quality of cognitive exchange in the learning process and reflects their attitudes and ideas for the application of innovative approaches in the educational environment.

- "Matrix for Students' self-assessment of the Learning Environment" - records the actual state of the learning environment as a system of influences and highlights the specific features of cognitive exchange, ensuring the acquisition of independent competency by the subjects in the pedagogical interaction.

In the operational aspect, a compounded study of teachers' self-evaluation and the parallel-reflecting assessment of the students is conducted. Teachers and students rating markers are measured by a three-dimensional scale: - for teachers 'self-assessment: (1) "do it"; (2) "do it partially"; (3) "do not do it" see Table 2.

- for students 'self-assessment: (1) "do it"; (2) "do it partially"; (3) "do not do it" see Table 3. 
Table 2. Matrix for Teacher Self-Assessment of the Learning nvironment

\begin{tabular}{|c|c|c|c|c|}
\hline \multirow{2}{*}{$\begin{array}{l}\text { № } \\
1\end{array}$} & \multirow{2}{*}{$\begin{array}{c}\text { Factors-Criteria } \\
\text { REPRODUCIBILITY - PROACTIVENESS }\end{array}$} & \multicolumn{3}{|c|}{ Statements } \\
\hline & & 1 & 2 & 3 \\
\hline \multirow{8}{*}{ 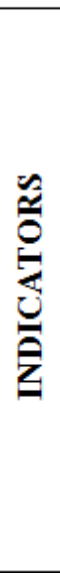 } & $\begin{array}{l}\text { I clarify the understanding of ideas and concepts through their direct demonstration and } \\
\text { research in a realistic context. }\end{array}$ & & & \\
\hline & $\begin{array}{l}\text { I provide the conditions for discovering the links between the different subject areas and } \\
\text { the application of the studied material in different aspects of life. }\end{array}$ & & & \\
\hline & I encourage cooperative learning to re-construct knowledge through networking. & & & \\
\hline & $\begin{array}{l}\text { I encourage the students' experimentation and research activity through continuous } \\
\text { observation, questioning, making assumptions, testing hypotheses, formulating } \\
\text { concepts. }\end{array}$ & & & \\
\hline & $\begin{array}{l}\text { I create conditional situations with a highly relevant context and provoke dialogue with } \\
\text { students in game situations. }\end{array}$ & & & \\
\hline & I use the resources of e-learning to enhance the digital skills of students. & & & \\
\hline & I set up performance tasks that unexpectedly deepen specific knowledge and skills. & & & \\
\hline & $\begin{array}{l}\text { I place students in the role of lecturers and allow them to manage the pedagogical } \\
\text { process. }\end{array}$ & & & \\
\hline 2 & PERSONALIZING - DIALOGIZING & 1 & 2 & 3 \\
\hline \multirow{13}{*}{ 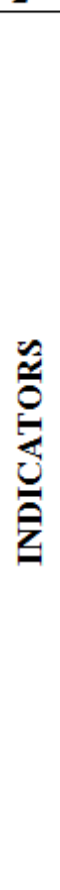 } & $\begin{array}{l}\text { I organize communication with students by creating a favorable atmosphere for learning } \\
\text { activities. }\end{array}$ & & & \\
\hline & $\begin{array}{l}\text { In the process of learning I group and regroup students thus, they can get to know each } \\
\text { other's strengths and resources. }\end{array}$ & & & \\
\hline & I organize face-to-face interaction through group work, teamwork, partner work. & & & \\
\hline & I use stimulating exercises to activate cognitive exchange. & & & \\
\hline & $\begin{array}{l}\text { I use methods to provoke thinking and generate ideas: brainstorming, associative cloud, } \\
\text { mental maps, visualizations. }\end{array}$ & & & \\
\hline & $\begin{array}{l}\text { I give feedback on the work and achievements of students and insist on receiving } \\
\text { feedback on the communication process. }\end{array}$ & & & \\
\hline & $\begin{array}{l}\text { I develop skills for positive dependence in the learning process by encouraging work in } \\
\text { an information network for expert problem solving and interpersonal experimenting. }\end{array}$ & & & \\
\hline & $\begin{array}{l}\text { I develop the experimental and research activities of the students through the project } \\
\text { method, a method of concrete situations. }\end{array}$ & & & \\
\hline & $\begin{array}{l}\text { I integrate the students' previous experience in introducing new areas of knowledge by } \\
\text { solving case studies, simulations, role-plays. }\end{array}$ & & & \\
\hline & I develop individual competence through modelling, designing research tasks. & & & \\
\hline & I give students the opportunity to argue opinions and construct their own judgments. & & & \\
\hline & I encourage a group analysis: sharing, comparison, debating. & & & \\
\hline & I develop skills for critical thinking and debating. & & & \\
\hline
\end{tabular}

I consider the individual differences and fluctuations in the learning process.

I recognize the impact of the social and cultural identity of students.

I work on building up skills for current self-assessment and reflection.

I encourage research, experimentation and independent studies of students.

$\approx$ I support training in real organizations based on contracts.

I I encourage student volunteering in educational institutions.

Exercise is applied.

I encourage the inclusion of students in learning communities and groups.

I apply practices for expert learning.

Z I apply experiential learning techniques.

I apply learning techniques by doing / acting.

I assign tasks according to the students' learning styles.

Provide time for consultation in real and virtual environments.

I encourage interpersonal communication in the learning process. 
Gergana Dyankova (2018) - Research of cognitive exchange specifics in teachers academic training International Journal of Cognitive Research in Science, Engineering and Education (IJCRSEE), 6(3), 1-14

Table 3. Matrix for Students`self-assessment of the Learning Environment

\begin{tabular}{|c|c|c|c|c|}
\hline № & Factors - criteria & & ten & \\
\hline 1 & REPRODUCIBILITY - PROACTIVENESS & 1 & 2 & 3 \\
\hline \multirow{8}{*}{ 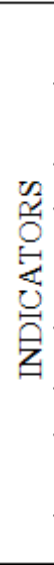 } & $\begin{array}{l}\text { The teacher helps to understand ideas and clarify concepts by direct demonstration and research } \\
\text { in a realistic context. }\end{array}$ & & & \\
\hline & $\begin{array}{l}\text { The teacher provides the conditions for discovering the links between the different subject areas } \\
\text { and the application of the studied material in different aspects of life. }\end{array}$ & & & \\
\hline & The teacher assigns tasks for group work, teamwork and networking. & & & \\
\hline & $\begin{array}{l}\text { The teacher requires the results of continuous observation of objects and phenomena; self- } \\
\text { constructing questions and making assumptions; evidence from hypothesis testing and } \\
\text { formulation of concepts. }\end{array}$ & & & \\
\hline & The teacher uses the gaming methods in the learning process. & & & \\
\hline & The teacher applies ICT in training and stimulates the enhancement of students' digital skills. & & & \\
\hline & $\begin{array}{l}\text { The teacher puts out non-standard, atypical implementation tasks that inadvertently deepen } \\
\text { specific knowledge and skills. }\end{array}$ & & & \\
\hline & The lecturer reasserts his role as a student and allows them to manage the pedagogical process. & & & \\
\hline 2 & PERSONALIZING - DIALOGIZING & 1 & 2 & 3 \\
\hline
\end{tabular}

The teacher creates a favourable atmosphere for leaming activity.

The teacher assigns tasks to groups and always rearranges their composition

The lecturer includes students in group work, teamwork, partner work.

The teacher uses specific exercises and diversifies the activities to keep the students' attention

The teacher provokes thinking and encourages the generation of ideas using brainstorming,

associative cloud, mental maps, and visualizations.

The teacher gives feedback on the work and achievements of students and insists on receiving

T2 their feedback on the communication process.

The lecturer encourages students' work in information networks to expertly solve tasks and

develops skills for interpersonal experimentation.

The lecturer develops the experimental and research activities of students by assigning group and

之 individual project activities.

The lecturer examines the available experience of the students and only then introduces them to new areas of knowledge.

The teacher stimulates individual competence through modelling, designing research tasks.

The lecturer provides an opportunity for students to give feedback and construct their own ideas.

The teacher provokes a group analysis by inviting students to share, compare views, and debates.

The teacher develops critical thinking skills and asserts his / her own ideas.

The teacher provokes the student's initiative to demonstrate their knowledge to the academic community.

$\underline{3}$

INDIVDUALIZATION - DIFFERENTIATION $\begin{array}{lll}1 & 2 & 3\end{array}$

The teacher works individually with students experiencing learning difficulties.

The teacher respects the social and cultural identity of the students.

The lecturer works on building up skills for ongoing self-assessment and reflection.

The lecturer encourages the study, experimentation and independent studies of students.

The teacher supports training in real organizations based on contracts.

The teacher encourages student volunteering in educational institutions.

The teacher recognizes the role of the professional-pedagogical experience in the specialty,

The teacher informs students about functioning learning communities and groups.

The teacher knows the strengths of the students and skilfully uses this expertise in assigning

Z group tasks.

The teacher applies experiential learning techniques.

The teacher applies leaming techniques by doing / acting.

The teacher assigns assignments according to the students' leaming styles.

The lecturer provides consultations in a real and virtual environment.

The teacher encourages interpersonal communication in the learning process. 
The data obtained ensures an objective analysis as they provide data from a parallel study of both parties (trainer, trainee) in the higher education process.

- FOURTH STAGE: Analysis of results and identification of resources for enhancing the quality of cognitive exchange in the learning process: the results obtained are summarized and systematized in order to realize the need to transform the educational environment; rethinking past pedagogical practices in academic teacher education; responding in a timely manner to the users of educational services in a dynamically changing world.

\section{RESULTS, ANALYSIS AND DISCUSSIONS}

\subsection{Analysis of the theoretical basis on the essence, characteristics, and effectiveness of innovative educa- tional approaches in the academic teacher education}

In the field of higher pedagogical education, the quality of educational services is proportional to the effectiveness of cognitive exchange in the learning process. This interpersonal relationship is based on the recognition that "quality" is a term of cultural values that are constantly developing and negotiating.

Thus, this dynamic characteristic of the term "quality" provides a methodological platform for professional discussions at a national and international level and it provides a basis for the methodological expertise of effective educational policies and approaches.

In the process of their selection and analytical interpretation, both the characteristics of the modern society in terms of information technology, technology, digitization, artificial intelligence are considered; globalization, alienation, multicultural diversity, etc., as well as their explanatory theoretical concepts.

Indeed, the most popular among them are the theories of constructivism with representatives of Lev Vygotsky (Vygotsky, 2004), Jean Piaget, (Piaget, 1992), John Dewey (Dewey, 1997), the concepts of the integral society of Michael Laitman and Anatoly Ulyanov (Laitman, Ulyanov 2011), the research of the movement of society and the changing knowledge base - "knowledge capacity" by
Gordon Moore (Isaacson, 2014); (Siemens, 2005), Richard S. Florida's Creative Class (Florida, 2017), Charles Landry's Creative City (Landri, 2005), Creative Schools (Robinson, Aronia, 2017) etc. A unifying motif in the analysis of the stated theories is the striving to advance and embrace the innovative educational approaches necessary for the qualitative professional training of the students - future teachers.

The marked features of modern society highlight the attributes of cognitive exchange in the learning environment.

In the context of this study, the specificity of cognitive exchange (deployment method) reveals the tendencies in subjects' reaction to events in the learning process and highlights their interpretations of future behavior in the learning environment. This dialectical attachment implies that both the intrinsic (attitudes, character, disposition of the subjects) and the external (managing the actual educational situation) attribute function is crucial for the quality of cognitive exchange in the learning process.

\subsection{The research results of the specificity of cognitive exchange in the academic process of the aca- demic teachers training}

The research covers 30 teachers and 140 students, a total of 170 representatives of 15 majors in the fields "Pedagogy" and "Pedagogy of training in sectors and types of sciences".

Differentiated as Component 1, the criterion "Reproducibility - Proactiveness" (Table 4, Diagram 1) denotes the polarity of applied pedagogical approaches in the educational environment:

- the traditional one, guaranteeing a safe working basis and preferred by the teachers who "do not think it is necessary to continuously analyze and enrich their own teaching experience" (Stošić and Stošić, 2013);

- and the interactive, complementary roles in cognitive exchange, because it "allows partners in the relationship to identify themselves and others correctly, accurately embody the expected roles and play them appropriately" (Tasevska, Kaleynska, Dyankova, 2015).

As a basic feature of the learning environment, we define the dynamics of reproducibility-proactivity because we are con- 
vinced that it is "the synergy of planning and management processes that is a solid basis for modeling a perspective concept in educational institutions" (Mirascieva, Koseva, 2018) focused on the quality of educational services.

Table 4. Results. Factor 1 „Reproducibility - proactiveness"

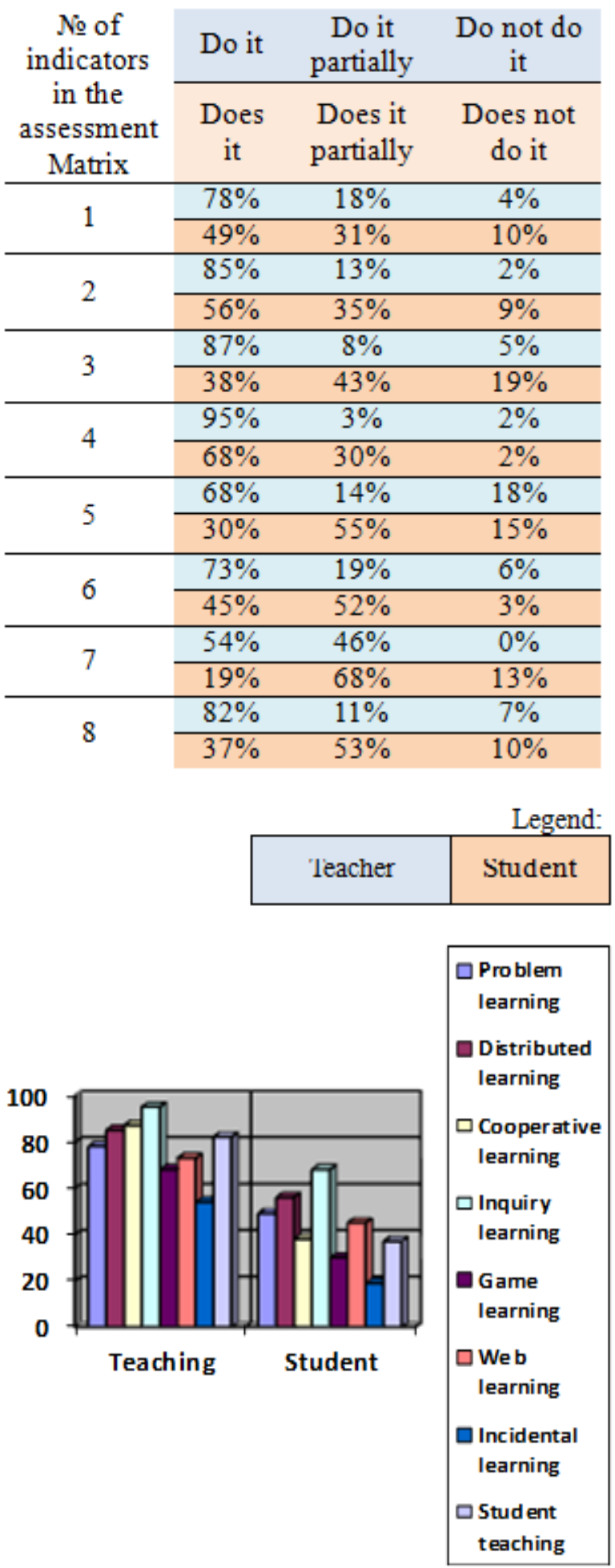

The second factor-criterion in the assessment matrixes is the Personalization-Dialogization component, which aims to examine how cognitive exchange influences the search of meaning in the learning process (Table 5, Diagram 2).

The fundamental thesis is that learning is a dialogue and at the same time it is oriented towards the individual participation of the students. In the focus of the learning process are researches, problem formulation and collaboration with others. The role of the lecturer is crucial to stimulate, to facilitate the variety of learning activities in which students analyze the links between the facts and conceptualize new knowledge.

Table 5. Results. Factor 2 "Personalization-Dialogizing"

\begin{tabular}{|c|c|c|c|}
\hline \multirow{2}{*}{$\begin{array}{l}\text { № of } \\
\text { indicators in } \\
\text { the } \\
\text { assessment } \\
\text { Matrix }\end{array}$} & \multicolumn{2}{|r|}{$\begin{array}{c}\text { Do it } \\
\text { partially }\end{array}$} & Do not do it \\
\hline & $\begin{array}{c}\text { Does } \\
\text { it }\end{array}$ & $\begin{array}{l}\text { Does it } \\
\text { partially }\end{array}$ & $\begin{array}{c}\text { Does not do } \\
\text { it }\end{array}$ \\
\hline \multirow[b]{2}{*}{1} & $82 \%$ & $18 \%$ & $0 \%$ \\
\hline & $45 \%$ & $33 \%$ & $22 \%$ \\
\hline \multirow{2}{*}{2} & $64 \%$ & $28 \%$ & $8 \%$ \\
\hline & $38 \%$ & $22 \%$ & $40 \%$ \\
\hline \multirow{2}{*}{3} & $76 \%$ & $22 \%$ & $2 \%$ \\
\hline & $35 \%$ & $23 \%$ & $42 \%$ \\
\hline \multirow[b]{2}{*}{4} & $18 \%$ & $43 \%$ & $39 \%$ \\
\hline & $13 \%$ & $24 \%$ & $63 \%$ \\
\hline \multirow{2}{*}{5} & $67 \%$ & $33 \%$ & $0 \%$ \\
\hline & $26 \%$ & $18 \%$ & $56 \%$ \\
\hline \multirow{2}{*}{6} & $86 \%$ & $14 \%$ & $0 \%$ \\
\hline & $35 \%$ & $43 \%$ & $22 \%$ \\
\hline \multirow[b]{2}{*}{7} & $79 \%$ & $19 \%$ & $2 \%$ \\
\hline & $31 \%$ & $23 \%$ & $46 \%$ \\
\hline \multirow{2}{*}{8} & $96 \%$ & $4 \%$ & $0 \%$ \\
\hline & $24 \%$ & $49 \%$ & $27 \%$ \\
\hline \multirow{2}{*}{9} & $100 \%$ & $0 \%$ & $0 \%$ \\
\hline & $67 \%$ & $33 \%$ & $0 \%$ \\
\hline \multirow[b]{2}{*}{10} & $100 \%$ & $0 \%$ & $0 \%$ \\
\hline & $65 \%$ & $33 \%$ & $2 \%$ \\
\hline \multirow{2}{*}{11} & $100 \%$ & $0 \%$ & $0 \%$ \\
\hline & $68 \%$ & $22 \%$ & $10 \%$ \\
\hline \multirow{2}{*}{12} & $94 \%$ & $6 \%$ & $0 \%$ \\
\hline & $47 \%$ & $38 \%$ & $15 \%$ \\
\hline \multirow{2}{*}{13} & $95 \%$ & $5 \%$ & $0 \%$ \\
\hline & $38 \%$ & $48 \%$ & $14 \%$ \\
\hline \multirow{4}{*}{14} & $83 \%$ & $13 \%$ & $4 \%$ \\
\hline & $36 \%$ & $51 \%$ & $13 \%$ \\
\hline & & & Legend: \\
\hline & & leacher & Student \\
\hline
\end{tabular}
tiveness"

Diagram 1. „Reproducibility - Proac- 


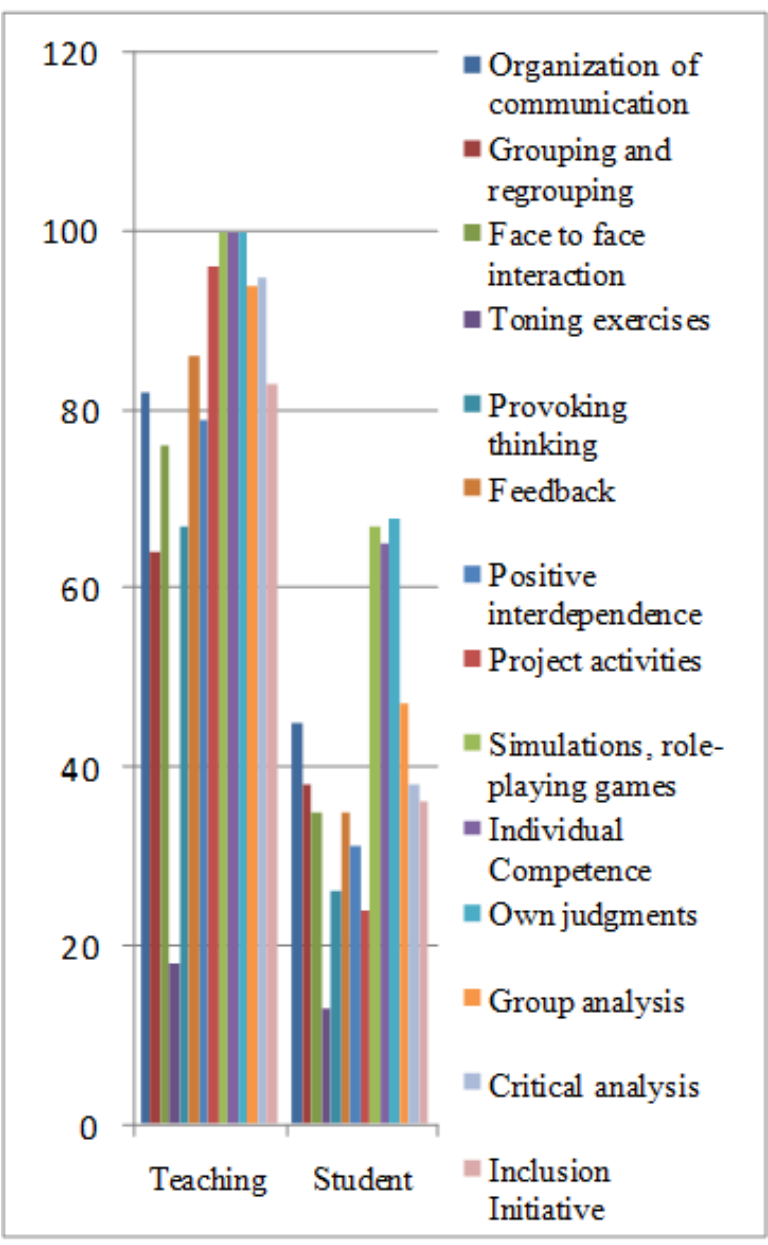

Diagram 2. Personalization-Dialogizing"

As the third component in the content parameters of the educational environment is determined the Factor-Criterion "Individualization-Differentiation" (Table 6, Diagram 3).

The focus is on the individual differences and the choice of technology to implement pedagogical interaction, given the preferred learning style (visual/verbal, consistent, global).

Resource-based teaching strategies are also explored in the context of practical activities in a real environment: volunteering, professional experience, contracts with employers, inclusion in learning communities, in personalized and technological networks.
Table 6. Results. Factor 3 "Individualization - Differentiation"

\begin{tabular}{|c|c|c|c|}
\hline \multirow{2}{*}{$\begin{array}{l}\text { № of } \\
\text { indicators } \\
\text { in the } \\
\text { assessment } \\
\text { Matrix }\end{array}$} & Do it & $\begin{array}{c}\text { Do it } \\
\text { partially }\end{array}$ & Do not do it \\
\hline & $\begin{array}{c}\text { Does } \\
\text { it }\end{array}$ & $\begin{array}{c}\text { Does it } \\
\text { partially }\end{array}$ & $\begin{array}{c}\text { Does not do } \\
\text { it }\end{array}$ \\
\hline \multirow{2}{*}{1} & $78 \%$ & $22 \%$ & $0 \%$ \\
\hline & $56 \%$ & $15 \%$ & $29 \%$ \\
\hline \multirow{2}{*}{2} & $72 \%$ & $28 \%$ & $0 \%$ \\
\hline & $62 \%$ & $10 \%$ & $28 \%$ \\
\hline \multirow{2}{*}{3} & $81 \%$ & $2 \%$ & $17 \%$ \\
\hline & $69 \%$ & $11 \%$ & $20 \%$ \\
\hline \multirow{2}{*}{4} & $76 \%$ & $24 \%$ & $0 \%$ \\
\hline & $51 \%$ & $18 \%$ & $31 \%$ \\
\hline \multirow[b]{2}{*}{5} & $67 \%$ & $23 \%$ & $10 \%$ \\
\hline & $32 \%$ & $19 \%$ & $49 \%$ \\
\hline \multirow{2}{*}{6} & $69 \%$ & $15 \%$ & $16 \%$ \\
\hline & $45 \%$ & $27 \%$ & $27 \%$ \\
\hline \multirow[b]{2}{*}{7} & $95 \%$ & $5 \%$ & $0 \%$ \\
\hline & $61 \%$ & $7 \%$ & $32 \%$ \\
\hline \multirow[b]{2}{*}{8} & $73 \%$ & $22 \%$ & $5 \%$ \\
\hline & $63 \%$ & $17 \%$ & $20 \%$ \\
\hline \multirow[b]{2}{*}{9} & $84 \%$ & $26 \%$ & $0 \%$ \\
\hline & $31 \%$ & $35 \%$ & $34 \%$ \\
\hline \multirow[b]{2}{*}{10} & $59 \%$ & $37 \%$ & $4 \%$ \\
\hline & $27 \%$ & $24 \%$ & $29 \%$ \\
\hline \multirow{2}{*}{11} & $63 \%$ & $37 \%$ & $0 \%$ \\
\hline & $35 \%$ & $23 \%$ & $32 \%$ \\
\hline \multirow[b]{2}{*}{12} & $72 \%$ & $22 \%$ & $6 \%$ \\
\hline & $46 \%$ & $27 \%$ & $27 \%$ \\
\hline \multirow{2}{*}{13} & $100 \%$ & $0 \%$ & $0 \%$ \\
\hline & $94 \%$ & $6 \%$ & $0 \%$ \\
\hline \multirow{4}{*}{14} & $100 \%$ & $0 \%$ & $0 \%$ \\
\hline & $98 \%$ & $2 \%$ & 0 \\
\hline & & & Legend: \\
\hline & & leacher & Student \\
\hline
\end{tabular}




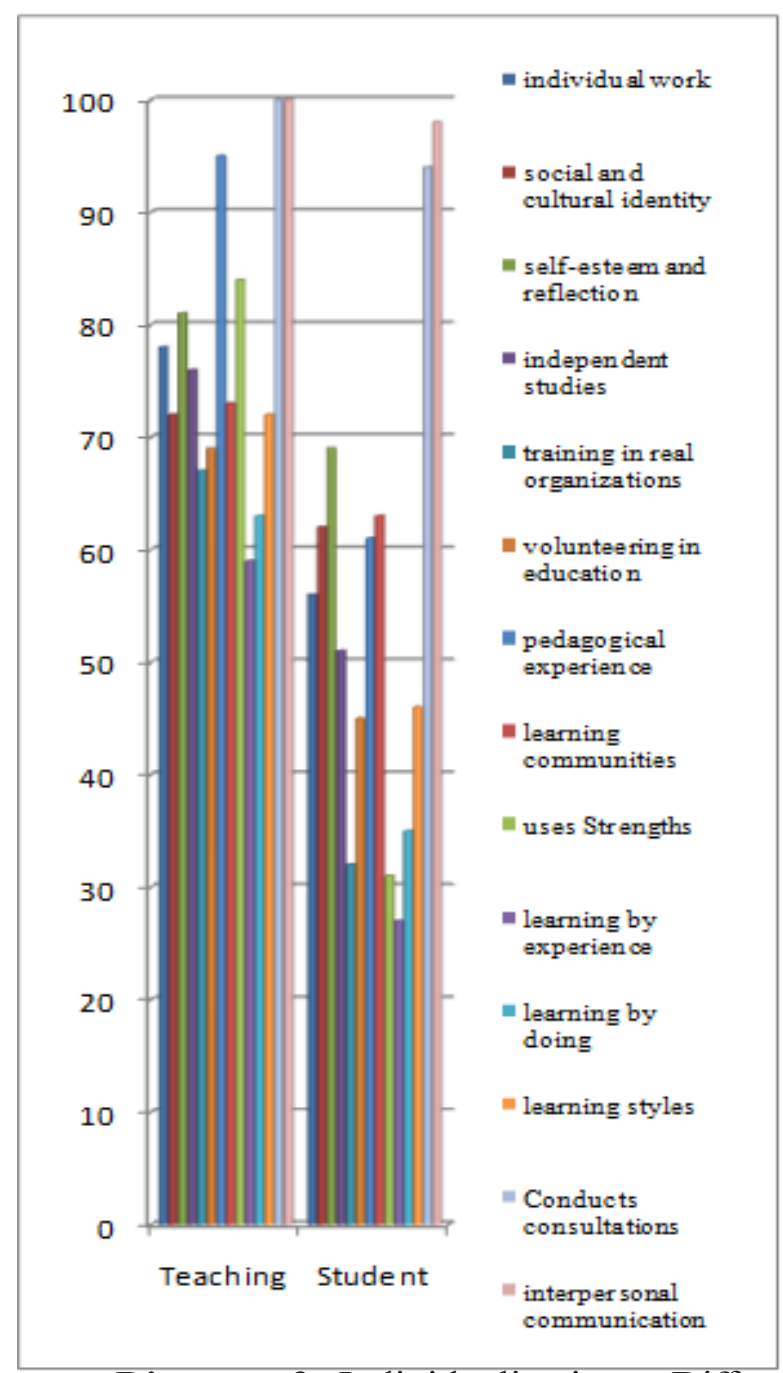
entiation

Diagram 3. Individualization - Differ-

\subsection{Analysis of results and discussion}

Analysis of results and discussion of the effects of the study is based on data processing from the two main tools:

- "Matrix for Teachers`Self-Assessment of the Learning Environment"

-"Matrix for Students' self-assessment of the Learning Environment"

It is important to note that the study provided specific data on the approaches and work methods of each of the teachers included in this research, however here the summarized and analyzed information is finally commented.

The tabular and graphical results representation of the first factor-criterion "Reproducibility-Proactiveness" reveals a very colorful picture in terms of value.
The impression is that values that report the high level of active practice indicators in the learning process predominate in teacher self-assessment. Their variation in the "Do It" column ranges from $54 \%$ to $95 \%$.

Conversely, their low level of performance ranging from $19 \%$ to $68 \%$ (reflected in the "Do It" column) is observed in the student assessment.

The analytical interpretation of the data outlines the paradoxical state of higher pedagogical education:

- on the one hand, the teachers state that they are conducting a learning process oriented towards active practices with the students;

- on the other hand, findings from students' opinions reveal a reverse tendency, namely, low satisfaction with their use in the learning process.

An explanatory approach to the observed discrepancies in the percentage ratio of the marked claims is found in the typical trends of this type:

- the self-assessment is a process in which the subjects unconsciously choose those statements in the reflecting scale, which rather express the DESIRED behavior;

- the assessment is a process where subjects predominantly focus on FACTS, reflecting difficulties in implementing the "expected" behavior.

It is the conditional observation of these two tendencies that makes it possible to objectively observe the fact that in the higher pedagogical education, despite the insufficient categorization of the indicators that consider the active practices in the educational process, the reform for the introduction of proactive pedagogical technologies has started.

An additional justification for this statement is the students' record in the "Does it partially" column, which reports relatively high values of Active Practice indices - ranging from $30 \%$ to $68 \%$ - against the low data values in the "Does not do it", ranging from $2 \%$ to $19 \%$.

At a brief glance, this internal correlation in this analysis reflects the actual orientation of part of the teachers towards the active practices in the learning process.

In concrete, their implementation is examined through the results of the additional Factors-Criteria "Personalization - Dialogization" and "Individualization - Differentiation".

The indicators that structure the cognitive exchange in such researched parameters reveal two layers of analysis:

- First, teachers' willingness to direct 
the system of influences in the learning process to the leading cognitive sphere analysis systems (visual, auditory, and kinetic).

Of key importance here are teachers and students markers confirming the application of specific techniques: organization of communication; for grouping and regrouping; for face-to-face interaction; energizing and toning; to provoke thinking and to generate ideas in the process of sharing and debating; to give feedback; for critical analysis; to formulate own through simulations, visualizations and role-plays; to discover the links between the facts on the basis of the student networking initiative. All of these determine the effective formative interactions of cognitive exchange.

The results processing again reveals high values of the $18 \%$ to $100 \%$ teachers markers in the "do it" column against the reflecting students' scores of $13 \%$ to $68 \%$ in the "Does it" column and $28 \%$ to $51 \%$ in the " Does it partially ".

Alarming is the varying student rating in the "Does not do it" column because its numerical values are ranging from $0 \%$ to $53 \%$ and reflect the questionable manifestation of the discussed effective techniques for organizing the cognitive exchange.

The objective interpretation of the registered data reveals an insufficient manifestation of the changes aimed at personalizing and dialogizing the pedagogical process.

Secondly, in the context of this research, this means that the overall organization of the educational environment is considered low level:

- in enhancing subject-subjective character in the learning process;

- in stimulating student initiative and pedagogically appropriate targeting;

- in the improvement of the ratio between the frontal, group and individual forms of organization of the pedagogical process.

- Second: the willingness of university lecturers to structure the cognitive exchange on the dynamics of their attributive functions, activating thinking and experience as a single act of knowledge through communication, research, practical application.

Referring here are the statements affirming that the activity of the individual and group subject of the activity "manifests not so much in the process of performing the activity as in the moments of its self-development, its progressive development when it is formed, unfolded and transformed" (Dimitrov, 2012).

In this regard, the research aims at exploring key indicators that determine the indi- vidualization and differentiation of subjects in the learning process. The quantitative dimension of their manifestation reflects their degree of importance on the effectiveness of cognitive exchange in the learning environment.

The tabular representation of the coefficients obtained in the assessment matrixes reveals an inaccuracy in the degree of indicators occurrence.

In the matrix of teachers self-assessment with a high percentage (59\% to $100 \%)$ is the marker in the "Do It" column.

On the other hand, the registered low values in the student assessment matrix rebut the realism of the applied teaching skills to apply approaches and practices for individualization and differentiation in the learning process.

Excluding the values of the last three indicators, this is evidenced by the students register in the scale with the following possibilities:

- ,Does it” - from $27 \%$ to $63 \%$;

- "Does it partially" - from $2 \%$ to $65 \%$;

- "Does not do it" - from $4 \%$ to $31 \%$.

The discussed correlation ratios in the students' assessment of the application of approaches and practices for individualization and differentiation in the learning process reveal rather low levels of expression in the learning environment.

In its third approximation, the analysis of the results highlights the urgent need for:

- changing the traditionally established models in the organization of the teaching process in the higher pedagogical education;

- applying student-oriented practices to stimulate self-organization in learning;

- the creation of a proactive technology that combines the characteristics of formal and non-formal education in a networked and technological environment.

\section{CONCLUSIONS}

Summarizing the key educational environment parameters determine it as a factor mediating the processes of self-assessment, reflection, and self-organization in pedagogical interaction. The purpose of this current wording is to transform cognitive exchange into the academic training of future teachers.

The thesis that the proactive learning environment is the necessary and sufficient condition ("Sine qua non") in the process towards the achievement of cognitive efficiency in education is strongly supported. 
In summary, the actual content of the proactive learning environment can be derived:

In the foreground, the procedural authenticity (connectivity) of the subjects, which is based on sharing, comparison, and debate. As natural mechanisms of cognitive exchange, these phenomena allow the subject not only to specify its own meanings but also to help others to specify their meanings.

This environment provides the conditions for maximum personalization of the learning process by transforming the traditional transmission process of educational communication into an organic and authentic dialogue.

Indeed, the acquisition of independent (autonomous) competence by the subjects in pedagogical interaction is a key determinant and indicator of the quality of the cognitive exchange in the learning process.

The inherent potential of the proactive educational environment is indisputable:

- to promote learning in the context of intensive interaction; sources;

- to support the full use of available re-

- overcome barriers to interpersonal communication;

- Produce skills acquisition for concentrated employment and enhanced collaboration.

These qualitative features designate the proactive educational environment as a technology platform that imposes the need for educational services in modern conditions.

\section{ACKNOWLEDGEMENTS}

The research is conducted with support of Southwest University "Neofit Rilski" by Internal research funding program for research projects (RP-A6 / 18).

\section{REFERENCES}

Covey, S. (2010). Sedemte navika na visoko efektivnite hora [The Seven Habits of Highly Effective People] Publ. Kibea, Sofia.

Dermendjieva, S. (2006). Poznavatelno vzaimodejstvie $\mathrm{v}$ mulitmediynata sreda i transformacia na detskata igra, [Cognitive interaction in a multimedia environment and transformation of children's play] Sofia, p. 35.

Dewey, J. (1997) Psihologia i pedagogika mishlenia [Psychology and pedagogy of thinking], Moskow.

Dimitrov, D. (2012). Obogatyavashtoto pedagogichesko vzaimodejstvie $\mathrm{v}$ preduchilishtna vuzrast
[Enriching pedagogical interaction at preschool age] P. Art, Sofia, p.108.

Florida, R. (2017). The new urban crisis: How our cities are increasing inequality, deepening segregation, and failing the middle class-And what we can do about it. Basic Books.

Frankl, V. (2000). Man's Search for Ultimate Meaning. New York: Basic Books.

Isaacson, W. (2014). The innovators. Simon \&Schuster. 528 .

Ivanov, I. (2011). Po putya kum postmodernata didaktika // Obuchenieto kato put kum obrazovanieto. [On the way to postmodern didactics. // Education as a way to education.] A collection of materials for the $60^{\text {th }}$ anniversary of Professor Plamen Radev, p. 169-184. Retrieved from: https:// www.ivanpivanov.com/uploads/sources/99_Popytq-kam-postmodernata-didactika.pdf

John, D. (1997). Psihologia i pedagogika mishlenia [Psychology and pedagogy of thinking], Moskow.

Laitman, M. \& Ulyanov, A. (2011). Psihologia integralnogo soobshtestva (metodika integranogo vospitania). [Psychology of the integral community (the method of integral education)] Publ. Institute for Advanced Studies, Moscow.

Landry, C. (2005). Kreativnuy gorod. [The creative city], Moscow "Classics-21".

Lewin, K. (1980). Topologia i teoria poliya. Hrestomatia po istorii psihologii, [Topology and field theory. Reader on the history of psychology] Ed. P. Ya. Galperin, A. N. Zhdan, Moscow: Moscow State University.

Mavrodieva, M. (2009). Sazdavane na efektivna sreda za prepodavane i uchene. Rezultati ot Mejdunarodnoto izsledvane za prepodawane i uchene TALIS na Organizaciyata za ikonomichesko satrudnichestvo i razvitie. [Creating an effective environment for teaching and learning. Results of the TALIS International Study on Teaching and Learning of the Organization for Economic Cooperation and Development], Publ. CKOKO, p. 31 .

Milenkova, V., Peicheva, D., \& Marinov, M. (2018). Towards defining media socialization as a basis for digital society. International Journal Of Cognitive Research In Science, Engineering And Education (IJCRSEE), 6(2), 21-32. Retrieved from: https://doi.org/10.5937/ijcrsee1802021M

Mirascieva, Sn. \& Koseva, D. (2018). Modeling of perspective concepts in education - planning and management, Contemporary education - condition, challenges and perspective, "Goce Delcev" University, Stip, Macedonia, p. 348-355.

Piaget, J. (1992). Psihologia intelekta. Logika I psihologia. [Psychology of the intellect. Logic and psychology.] Moskow.

Robinson, K. \& Aronika, L. (2017). Kreativnite uchilishta. Revoluyciata koyato preobraziava obrazovanieto. [Creative Schools: Revolutionizing Education from the Ground]. RAABE, Sofia.

Siemens, G. (2005). Connectivism: A learning theory for the digital age. International journal of instructional technology \& distance learning. Ganuary, 2(1) p. 3-10. Retrieved from: http:// itdl.org/Journal/Jan 05/article01.htm

Stošić, L. \& Stošić, I. (2013). Diffusion of innovation in modern school. International Journal Of Cognitive Research In Science, Engineering And Education, 1(1), Retrieved from: http://www.ijcrsee. 
com/index.php/IJCRSEE/article/view/144

Tasevska, D., Kaleynska, T., Dyankova, G. (2015). Mladejko liderstvo - naruchnik za profesionalisti [Youth Leadership - A Handbook for Professionals] EIC, Veliko Tarnovo, p. 40.

Vardareva, V., Pashova, A. (2012). Specifika na magisturskata programa Interkulutrno obrazovanie ili za preodolyavaneto na informacionniyat model na obuchenie $\mathrm{v}$ universiteta, [The specificity of the masters program Intercultural education or for overcoming the information model for training at the university.] Educational technologies. Yearbook of Shumen University "Ep. K. Preslavski”" T. XVI D, p. 53-61.

Vygotsky, L. (2004). Psihologia razvitia rebenka, [Child developmental psychology], Moskow.

Yasvin, V. (2001). Obrazovatelnaya sreda ot modelirovania $\mathrm{k}$ preotkrivaniuy. [Educational environment from modeling to design] Publ. Meaning. Moscow.

Zakon za vissheto obrazovanie, [Higher Education] Act-Retrieved from: https://lex.bg/en/laws/ ldoc/2133647361 